University of Nebraska - Lincoln

DigitalCommons@University of Nebraska - Lincoln

Faculty Publications from the Harold W. Manter Laboratory of Parasitology

7-2005

\title{
Four New Cestode Species from the Spiral Intestine of the Round Stingray, Urobatis halleri, in the Northern Gulf of California, Mexico
}

\author{
Megan M. Friggens \\ University of Northern Arizona, mryan@sevilleta.unm.edu \\ Donald W. Duszynski \\ University of New Mexico, eimeria@unm.edu
}

Follow this and additional works at: https://digitalcommons.unl.edu/parasitologyfacpubs

Part of the Parasitology Commons

Friggens, Megan M. and Duszynski, Donald W., "Four New Cestode Species from the Spiral Intestine of the Round Stingray, Urobatis halleri, in the Northern Gulf of California, Mexico" (2005). Faculty Publications from the Harold W. Manter Laboratory of Parasitology. 186.

https://digitalcommons.unl.edu/parasitologyfacpubs/186

This Article is brought to you for free and open access by the Parasitology, Harold W. Manter Laboratory of at DigitalCommons@University of Nebraska - Lincoln. It has been accepted for inclusion in Faculty Publications from the Harold W. Manter Laboratory of Parasitology by an authorized administrator of DigitalCommons@University of Nebraska - Lincoln. 


\title{
Four New Cestode Species from the Spiral Intestine of the Round Stingray, Urobatis halleri, in the Northern Gulf of California, Mexico
}

\author{
Megan M. Friggens ${ }^{1,3}$ and Donald W. Duszynski ${ }^{2}$ \\ ${ }^{1}$ School of Forestry, Northern Arizona University, Flagstaff, Arizona 86011, U.S.A. \\ (e-mail: mryan@sevilleta.unm.edu) and \\ ${ }^{2}$ Department of Biology, University of New Mexico, Albuquerque, New Mexico 87131, U.S.A. \\ (e-mail: eimeria@unm.edu)
}

ABSTRACT: The spiral intestines of 40 specimens of Urobatis halleri from the northern Gulf of California, Mexico, were examined for cestodes. Four new species, Rhinebothrium chollaensis n. sp., Rhinebothrium gravidum n. sp., Eutetrarhynchus cortezensis n. sp., and Prochristianella minima n. sp., are described. This is the first record of these 3 genera in the Gulf of California and the first report of Eutetrarhynchus in $U$. halleri.

KEY wORDS: Cestode, Trypanorhyncha, Tetraphyllidea, Rhinebothrium, Prochristianella, Eutetrarhynchus, Elasmobranch, Urobatis halleri, Sea of Cortez, Stingray.

During October of 1994 and 1995, 40 round stingrays, Urobatis halleri (Cooper, 1863), were collected from the northern Gulf of California near Puerto Peñasco, Sonora, Mexico. This article describes 4 new species of cestodes from the spiral intestine of $U$. halleri. Urobatis halleri (Rajiformes: Urolophidae) is a small marine elasmobranch $(=56.0$ $\mathrm{cm}$ length) inhabiting the benthos of beaches and bays (Eschmeyer et al., 1998). The order Rajiformes, to which Urobatis belongs, includes the skates (Rajidae and Anacanthobatidae), guitarfish (Rhinobatidae), stingrays (Dasyatidae, Plesiobatidae, Hexatrygonidae, Urolophidae, and Potamotrygonidae), and rays (Myliobatidae) (Eschmeyer et al., 1998). There are 4 genera and 44 species within Urolophidae: Urobatis comprise 6 species (Eschmeyer et al., 1998). Urobatis halleri has a conical-spiral intestine (Compagno, 1988), an organ unique to elasmobranches. This type of spiral intestine consists of a flap of tissue attached in a continuous spiral down its outer edge, creating whorls and increasing the absorptive surface of the organ (McVicar, 1979). Within U. halleri, these whorls form 13 distinct chambers. In this article, we report the results of our survey of the cestodes inhabiting Urobatis in the Northern Gulf of California, adding a new location to the previous cestode records for Urolophidae.

\section{MATERIALS AND METHODS}

Forty specimens of $U$. halleri were obtained from 2 localities in the northern Gulf of California near El Centro de Estudio de Desiertos y Oceanos (CEDO) in Puerto Peñasco, Sonora, Mexico, during October 1994 and 1995. One site

\footnotetext{
${ }^{3}$ Corresponding author.
}

was located in the intertidal zone off CEDO and the other, Cholla Bay, was located $23 \mathrm{~km}$ north of CEDO. Working from Cholla Bay, $31 \mathrm{U}$. halleri were captured using a beach seine. Nine $U$. halleri were collected with a Hawaiian sling behind the CEDO field station. All hosts were brought back to CEDO and either killed for immediate dissection or maintained in an aerated tank for later dissection. Each host was measured, weighed, and its sex determined before dissection. Only cestodes recovered from freshly killed hosts are considered in this study.

An incision was made on the ventral side of each animal and the digestive track was tied off with a thread anterior and posterior to the stomach and spiral intestine to prevent loss or migration of worms. The stomach and spiral intestine were removed, injected with AFA (5 part glacial acetic acid, 10 parts formalin, and 85 parts $85 \%$ ethanol) to fix the worms in situ and placed in a dish containing AFA for examination. Individual chambers of the spiral intestine were defined by using the dorsal blood vessel of the spiral intestine as a point of reference to determine the beginning and end of each valve. The contents of the spiral valve were examined with a stereomicroscope. Worms from each chamber of the spiral intestine were recovered and transferred to an appropriately labeled vial containing $10 \%$ formalin for storage.

Initially, cestodes were hydrated, stained with Semichon carmine, dehydrated in a graded ethanol series, cleared in Histoclear, and mounted in Canada balsam for examination with light microscopy. When work resumed on the remaining preserved cestodes 4 yr later, many worms were brittle and unreceptive to stain. To remove residual fixatives, these worms were washed 2-3 times through a hydration series to water and dehydrated to $70 \%$ ethanol. Following the technique outlined by Pritchard and Kruse (1982) for straightening worms fixed in situ, worms were left in $70 \%$ ethanol and glycerin for at least 2 mo (Pritchard and Kruse [1982] suggest $48 \mathrm{hr}$ ). Finally, cestodes were hydrated, stained with Semichon carmine or Van Cleave hematoxylin, dehydrated in a graded ethanol series, cleared in toluene, and mounted in Canada balsam or resin TM 90 (Bjørn Berland, Zoologisk Institutt, Bergen, Norway).

Cestodes reserved for scanning electron microscopy (SEM) were hydrated, postfixed in $1 \%$ buffered $(\mathrm{pH} 7.2)$ 
osmium tetroxide $\left(\mathrm{OsO}_{4}\right)$ for $1 \mathrm{hr}$, dehydrated in a graded ethanol series to absolute ethanol, critical-point dried in liquid $\mathrm{CO}_{2}$, mounted on aluminum stubs with double-sided tape and silver paint, coated with gold, and examined with a Hitachi S530 scanning electron microscope.

Friggens and Brown (2005) present a comprehensive description of the cestode community within $U$. halleri, including species list and infection characteristics. Cestodes were identified using the study of Khalil et al. (1990) in combination with reference to primary literature. The following type specimens were borrowed from the United States National Parasite Collection (USNPC), Beltsville, Maryland, for comparison: Acanthobothrium bajaensis Appy and Dailey, 1973 (paratype 72568), Acanthobothrium olseni Dailey and Mudry, 1968 (holotype 71216), Anthobothrium oligorchidum Young, 1954 (type 49096), Acanthobothrium parviuncinatum Young, 1954 (type 49095), Eutetrarhynchus geraschmidti Dollfus, 1974 (paratype 72513), Eutetrarhynchus schmidti Heinz and Dailey, 1974 (paratype 72669), Eutetrarhynchus thalassius Kovacs and Schmidt, 1980 (paratype 75229), Mecistobothrium myliobati Heinz and Dailey, 1974 (holotype 72673), Oncomegas paulinae Toth, Campbell, and Schnidt, 1992 (paratype 82187), Prochristianella fragilis Heinz and Dailey, 1974 (holotype 72676), Prochristianella minima Heinz and Dailey, 1974 (paratype 72678), Rhinebothrium flexile Linton, 1890 (voucher 07662), Rhinebothrium lintoni Campbell, 1970 (paratype 70560), Rhinebothrium minimum van Benenden, 1850 (voucher 07334; note specimen possesses a myzorhynchus), and Rhinebothrium urobatidium (Young, 1955) Appy and Dailey, 1977 (voucher 74599). Measurements are presented in micrometers as ranges, followed parenthetically by mean, standard deviation, and sample size, unless otherwise noted. Voucher specimens of $R$. urobatidium (92202-92205), A. parviuncinatum (92206, 92207), A. olseni (92208), O. paulinae (92209), M. myliobati (92210), P. minima (92211) and holotypes and paratypes of the new species were deposited in the USNPC.

\section{Rhinebothrium chollaensis $\mathrm{n} . \mathrm{sp}$. (Figs. 1-3)}

\section{Description}

With the characteristics of the genus. Based on 10 whole and 7 partial mounted specimens and 4 specimens examined by SEM. Worms $1.3-5.1 \mathrm{~mm}$ (3.0 $\pm 1.6 \mathrm{~mm}, 9)$ long, acraspidote $(n=11)$, apolytic, consisting of 32-84 (61.1 $\pm 15.2,9)$ proglottids. Scolex with 4 bothridia on short pedicles, spinose. Cephalic peduncle absent. Bothridia leaflike, with lobulated muscular rims, asymmetrically set upon pedicle; posterior of bothridium is considerably wider and slightly longer than anterior. Pedicles 37.5-125 (91.5 \pm 33.1, 5) long, 40-92.5 $(66.5 \pm 20,5)$ wide. A slight constriction exists where the bothridia meet the pedicle. Each bothridium with a single median longitudinal septum and numerous transverse septa forming 2 rows of loculi along the length of bothridium and a single loculus at each bothridial terminus. Loculi number 40-49 $(45 \pm 2.8,9)$.

Immature proglottids $15-35(24.3 \pm 6.2,11)$ long, $52.5-127.5(88.6 \pm 24.6,11)$ wide; mature proglottids $80-272.5(140.9 \pm 60.5,11)$ long, 47.5-155 $(118.1 \pm 30.6,11)$ wide. Terminal proglottids longer than wide, 130-452.5 (327.3 $\pm 97,11)$ long, 55142.5 (98 $\pm 33,11)$ wide. Conspicuous indentation at genital pore. Four testes $15-55(37.2 \pm 12.9,8)$ long, 15-27.5 (20.7 $\pm 4.5,8)$ wide, in 2 rows in anterior half of mature proglottids. Cirrus armed; cirrus sac centrally located and angled posteriorly, 57.5-75 (68.1 $\pm 8.5,4)$ long, 40-50 (44.7 $\pm 4.4,4)$ wide in mature proglottids, $37.5-72.5(57.6 \pm 13,8)$ long, $32.5-50(42.1 \pm 5.7,8)$ wide in gravid proglottids. Genital pore $60 \%$ of proglottid length from posterior end, irregularly alternating. Vagina anterior to cirrus sac, thick walled, widening distally to form atrium before winding posteriorly (in some specimens winding laterally then posteriorly) toward ovary. Ovary in posterior third to half of proglottid, U-shaped in dorsal-ventral view with symmetrical lobes that just reach the posterior margin of the cirrus sac. Ovarian lobes 87.5-258 $(159.6 \pm 48.3,11)$ long, 12.5-50 (32 $\pm 14.4,11)$ wide. Vitelline follicles small, in compact rows along length of proglottid.

\section{Taxonomic summary}

Type host: Haller's round ray, Urobatis halleri (Cooper, 1863).

Type locality: Puerto Peñasco, Sonora, Mexico $\left(31^{\circ} 18^{\prime} 27^{\prime \prime} \mathrm{N} ; 113^{\circ} 32^{\prime} 5^{\prime \prime} \mathrm{W}\right)$.

Site of infection: Spiral intestine, chambers 1-7.

Prevalence, mean intensity, abundance, and range of infection: 7\%, 21.0, $3.8( \pm 28.3)$, and $1-41$.

Species deposited: United States National Parasite Collection, Beltsville, Maryland, holotype (USNPC 92213) and paratype (USNPC 92214).

Etymology: The specific epithet, chollaensis, refers to Cholla Bay in which the host of the holotype specimen was collected.

\section{Remarks}

Seventeen Rhinebothrium species possess a median longitudinal septum and are similar in size $(\sim 1-6 \mathrm{~mm})$ to R. chollaensis: Rhinebothrium biorchidum Huber and Schmidt, 1985, Rhinebothrium rhinobati Dailey and Carvajal, 1976, Rhinebothrium paratrygoni Rego and Dias, 1976, Rhinebothrium xiamensensis Yanhai 


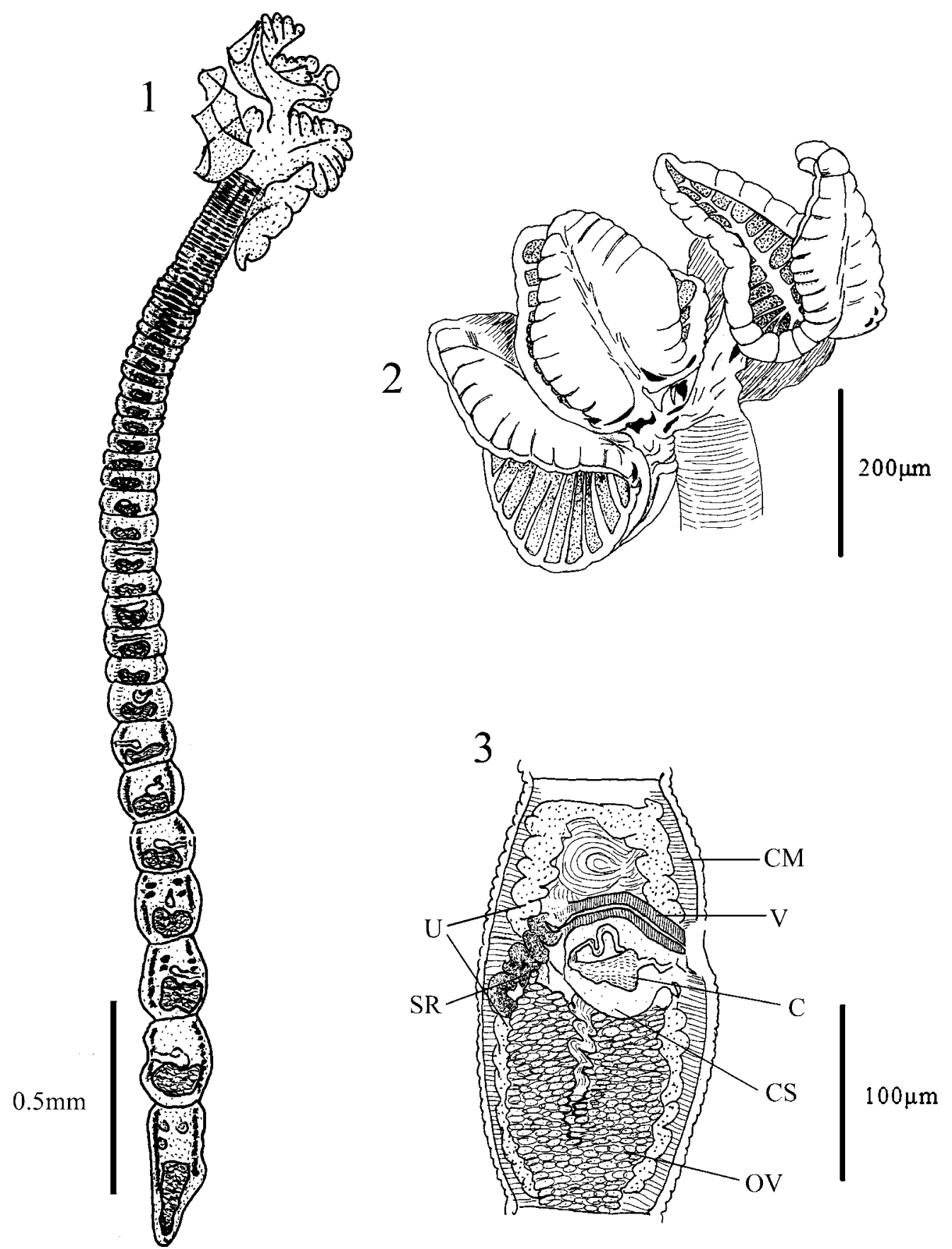

Figures 1-3. Rhinebothrium chollaensis n. sp. 1. Entire worm. 2. Scolex. 3. Early gravid proglottid. (C, cirrus; CM, circular muscle; CS, cirrus sac; OV, ovary; SR, seminal receptacle; U, uterus; V, vagina.)

and Wenchuan, 2001, Rhinebothrium longicolle Linton, 1890, R. urobatidium, Rhinebothrium scobinae Euzet and Carvajal, 1973, Rhinebothrium himatura Williams, 1964, Rhinebothrium hawaiensis
Cornford, 1974, R. lintoni Campbell, 1970, Rhinebothrium devaneyi Brooks and Deardorff, 1988, Rhinebothrium corymbum Campbell, 1975, Rhinebothrium euzeti Williams, 1958, Rhinebothrium 
cadenati Euzet 1954, Rhinebothrium tumidulum (Rudolphi 1819) Joyeux and Baer, 1936, Rhinebothrium margeritense Mayes and Brooks, 1981, and Rhinebothrium walga (Shipley and Hornel, 1905) Euzet, 1956. Testes number distinguishes $R$. chollaensis (4) from $R$. xiamensensis (10-14), R. longicolle (20-32), R. urobatidium (6-12), R. scobinae (19), R. himatura (19-20), R. hawaiensis (11-13), $R$. lintoni (5-8), $R$. devaneyi (30-43), $R$. corymbum (25), and $R$. euzeti (12). Furthermore, R. chollaensis possesses fewer loculi (40-49) than the latter 4 species, $R$. lintoni (54-56), $R$. devaneyi (128), $R$. corymbum (58), and $R$. euzeti (78); a greater number of loculi (40-49) than $R$. cadenati (4) and $R$. tumidulum (23); and, both a greater number of testes (4) and loculi (40-49) than $R$. biorchidum (2 and 2230 , respectively) and $R$. rhinobati (2 and 23 , respectively). Rhinebothrium biorchidum is further distinguished from $R$. chollaensis by distinctly hinged bothridia. Rhinebothrium chollaensis has fewer loculi than $R$. paratrygoni (40-49 vs. 72-76, respectively) and lacks the long cephalic peduncle of $R$. paratrygoni. Rhinebothrium margeritense, $R$. walga, and $R$. chollaensis possess a similar number of testes and loculi. The acraspidote segments of $R$. chollaensis distinguish it from $R$. margeritense and proglottid number distinguishes $R$. chollaensis from $R$. walga (32-80 vs. 15-25, respectively).

\section{Rhinebothrium gravidum $\mathrm{n}$. sp. (Figs. 4-8)}

\section{Description}

With the characteristics of the genus. Based on 8 mounted specimens and 1 specimen examined by SEM. Worms 1.8-5.3 mm (3.1 $\pm 1.4 \mathrm{~mm}, 5)$ long, acraspidote, apolytic, consisting of 9-21 (14.8 \pm 3.6, 8 ) proglottids. Scolex with 4 bothridia on short pedicles, spinose. Cephalic peduncle short or absent, 25-37.5 (30.8 $\pm 6.3,3)$ long, 87.5-105 (96.3 \pm 12.4 , 3) wide. Bothridia leaf-like, with lobulate muscular rims, asymmetrically set on pedicles; posterior of bothridium considerably wider and slightly longer than anterior. A slight constriction present where bothridium meets pedicle. Each bothridium possesses a single median longitudinal septum and numerous transverse septa forming 2 rows of loculi along length of bothridium and a single loculus at each terminus. Loculi number 46-56 (50.7 $\pm 5,3)$.

Immature proglottids 25-67.5 (45.6 \pm 16.56, 7) long, 47.5-176 (106.2 $\pm 42.8,7)$ wide; mature proglottids $132-354(222.4 \pm 81.8,11)$ long, 72.5-
$223(157.5 \pm 45,11)$ wide. Gravid proglottids elongate, 551-1,547 (909.8 \pm 412.1, 5) long, 117.5$180(156 \pm 23.7,5)$ wide. Testes 8-10 (8.7 \pm 0.95 , 7 ) in number, forming 2 rows in anterior half of mature proglottids, $23-44(35.7 \pm 6.3,11)$ long, 10 22.5 (14.9 $\pm 4.2,11)$ wide; atrophied in gravid proglottids. Cirrus armed, cirrus sac round, centrally located, 52.5-79 (69.1 $\pm 13.4,8)$ long, 27.5-69 (49.1 $\pm 17,8)$ wide in mature proglottids; 80-130 $(108.1 \pm 21.3$, 4) long, 60-82.5 (70 $\pm 9.4,4)$ wide in gravid proglottids. Genital pore $50-60 \%$ of proglottid length from end, irregularly alternating. Vagina opening into the genital atrium anterior to cirrus sac and coiling posteriorly toward ovary along midline of proglottids. Ovary located in posterior third of proglottid, $U$ shaped in dorsal-ventral view with symmetrical lobes that just reach posterior margin of cirrus sac. Ovarian lobes measure 50-135 $\times 25-70(96.9 \times 43.1)$. Uterus saccate, diverticulated in early gravid proglottids, occupying entire length of proglottid. Eggs spheroid with filament, 10-15 (13 \pm $2.5,6)$ across. Vitellaria form compact lateral bands along entire length of proglottid.

\section{Taxonomic summary}

Type host: Haller's round ray, Urobatis halleri (Cooper, 1863).

Type locality: Puerto Peñasco, Sonora, Mexico $\left(31^{\circ} 18^{\prime} 27^{\prime \prime} \mathrm{N} ; 113^{\circ} 32^{\prime} 52^{\prime \prime} \mathrm{W}\right)$.

Infection site: Spiral intestine, chambers 1-9.

Species deposited: United States National Parasite Collection, Beltsville, Maryland, holotype (USNPC 92212).

Prevalence, mean intensity, abundance, and range of infection: $18 \%, 2.4,0.9( \pm 2.6)$, and 1-7.

Etymology: The specific epithet, gravidum, refers to the typically gravid characteristic of the terminal proglottid of these specimens.

\section{Remarks}

Eighteen Rhinebothrium species possess a median longitudinal septum and are similar in size $(\sim 1-6 \mathrm{~mm})$ to $R$. gravidum: $R$. biorchidum, $R$. rhinobati, $R$. paratrygoni, $R$. xiamensensis, $R$. longicolle, $R$. urobatidium, $R$. scobinae, $R$. himatura, $R$. hawaiensis, $R$. lintoni, $R$. devaneyi, $R$. corymbum, $R$. euzeti, $R$. cadenati, $R$. tumidulum, $R$. margeritense, $R$. walga, and $R$. chollaensis. Testes number distinguishes 


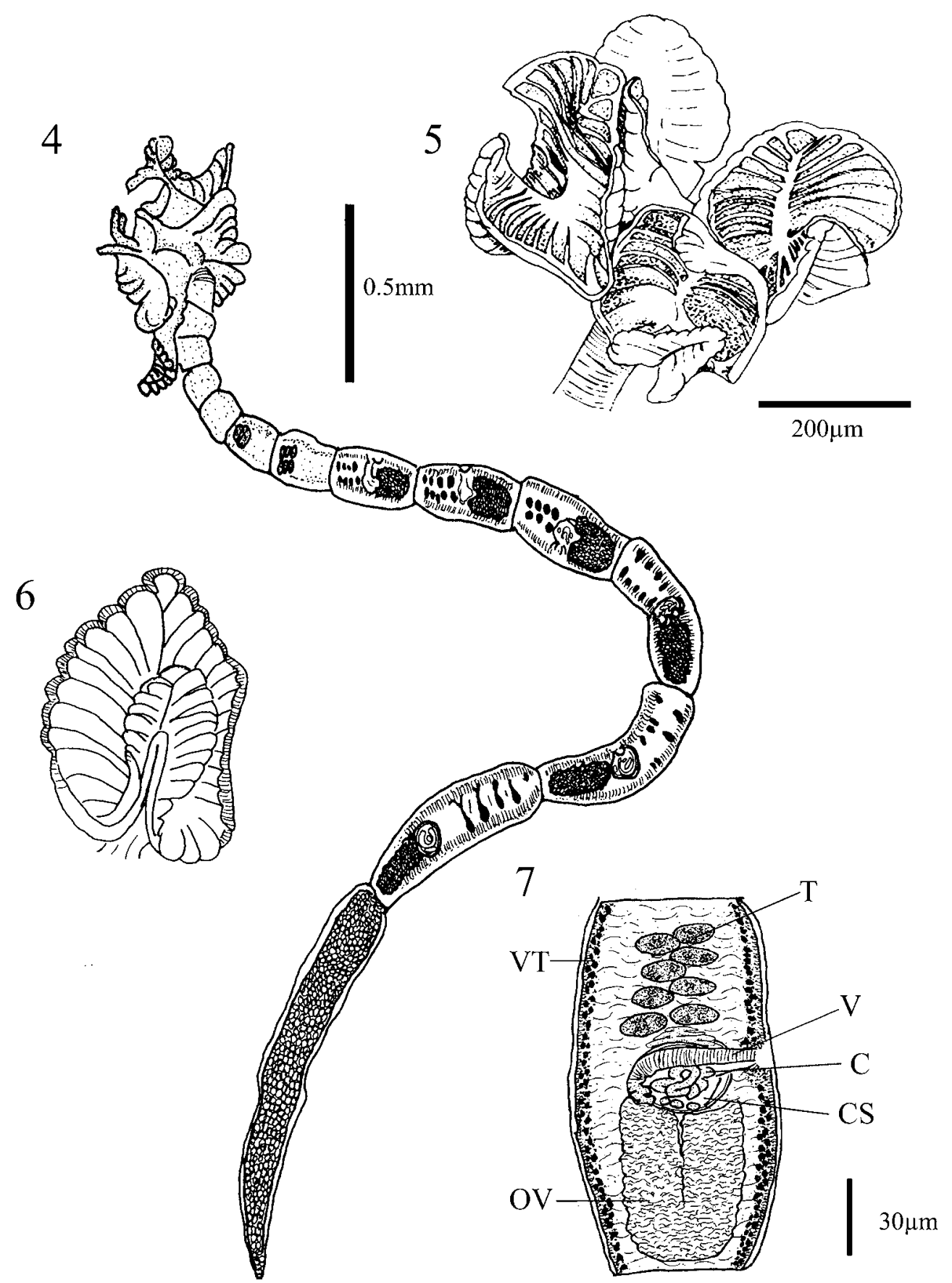

Figures 4-7. Rhinebothrium gravidum n. sp. 4. Entire worm. 5. Scolex. 6. Bothridium. 7. Mature proglottid. (C, cirrus; $\mathrm{CS}$, cirrus sac; OV, ovary; T, testes; V, vagina; VT, vitellaria.)

$R$. gravidum (8-10) from $R$. biorchidum (2), $R$. devaneyi (30-43), $R$. corymbum (25), and $R$. euzeti $R$. rhinobati (2), $R$. margeritense (3-6), $R$. walga (12). Rhinebothrium gravidum possesses a distinct (4-6), $R$. longicolle (20-32), $R$. scobinae (19), number of loculi (46-56) as compared with $R$. devaneyi $R$. himatura (19-20), $R$. hawaiensis (11-13), (128), R. corymbum (58), R. euzeti (78), $R$. cadenati 


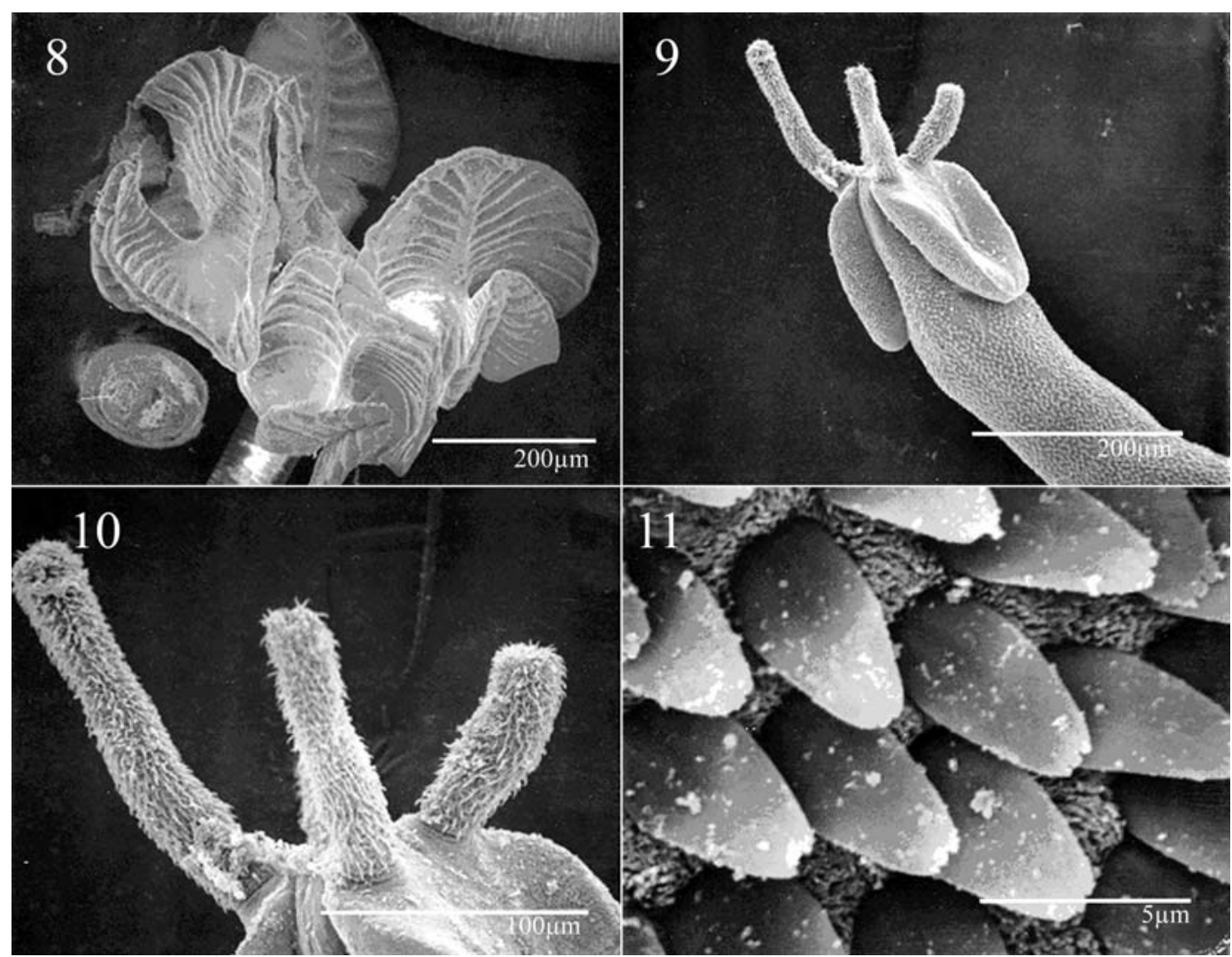

Figures 8-11. Scanning electron micrographs of Rhinebothrium gravidum n. sp. and Eutetrarhynchus cortezensis n. sp. 8. Scolex of $R$. gravidum. 9. Scolex of E. cortezensis. 10. Tentacles of E. cortezensis showing homeoacanthous nature of the armature. 11. Pectinate blade-like microtriches from proximate bothrial and pars bothridialis surfaces of the E. cortezensis scolex.

(4), R. tumidulum (23), R. hawaiensis (48), R. walga (42), R. scobinae (19), R. longicolle (32-40), R. urobatidium (38-48), Rhinebothrium spinicephalum (32), $R$. rhinobati (23), and $R$. biorchidum $(22-$ 30). Differences in loculi number distinguish $R$. gravidum (46-56 loculi) from $R$. devaneyi (128), $R$. corymbum (58), $R$. euzeti (78), $R$. cadenati (4), $R$. tumidulum (23), R. hawaiensis (48), R. walga (42), $R$. scobinae (19), R. longicolle (32-40), $R$. urobatidium (38-48), R. spinicephalum (32), R. rhinobati (23), and $R$. biorchidum (22-30). Rhinebothrium gravidum lacks the distinctly bilobed bothridia of $R$. biorchidum and $R$. corymbum, the long cephalic peduncle of $R$. paratrygoni, and the enlarged cirrus sac of $R$. xiamensensis. Rhinebothrium gravidum possesses markedly fewer segments (9-21) than $R$. lintoni $(>250)$. Rhinebothrium gravidum is distinguished from $R$. chollaensis by proglottid number (14 vs. 61) and loculi number (45 vs. 50).

\section{Eutetrarhynchus cortezensis $\mathrm{n} . \mathrm{sp}$.}

(Figs. 11-20)

\section{Description}

With the characteristics of the genus. Based on 9 whole mounted specimens and 2 specimens examined with SEM. Worms small, length $2.5-6.8 \mathrm{~mm} \mathrm{(3.7 \pm}$ $1.3 \mathrm{~mm}, 8)$, acraspidote, apolytic, consisting of 3-9 $(6.2 \pm 1.8,8)$ proglottids. Scolex, acraspidote with 2 patelliform bothria; pars bulbosa, pars vaginalis, and proximal surface of bothria covered by pectinate microtriches. Distal surface of bothria with no microtriches. Bothrial margins free; rims often notably thickened. Pars bothridialis 176-232 (204.6 \pm 12.9, 11) long; pars bulbosa 240-487.5 (412.6 \pm 83.5, 8) long, bulb width 54.5-90 (75.8 \pm 12.6, 8); pars vaginalis 422-742.5 (574.9 \pm 129.4, 9) long. Ratio pars bothridalialis:par bulbosa:pars vaginalis, 1.0:2.8:2.0. Tentacle sheaths slightly sinuous. 


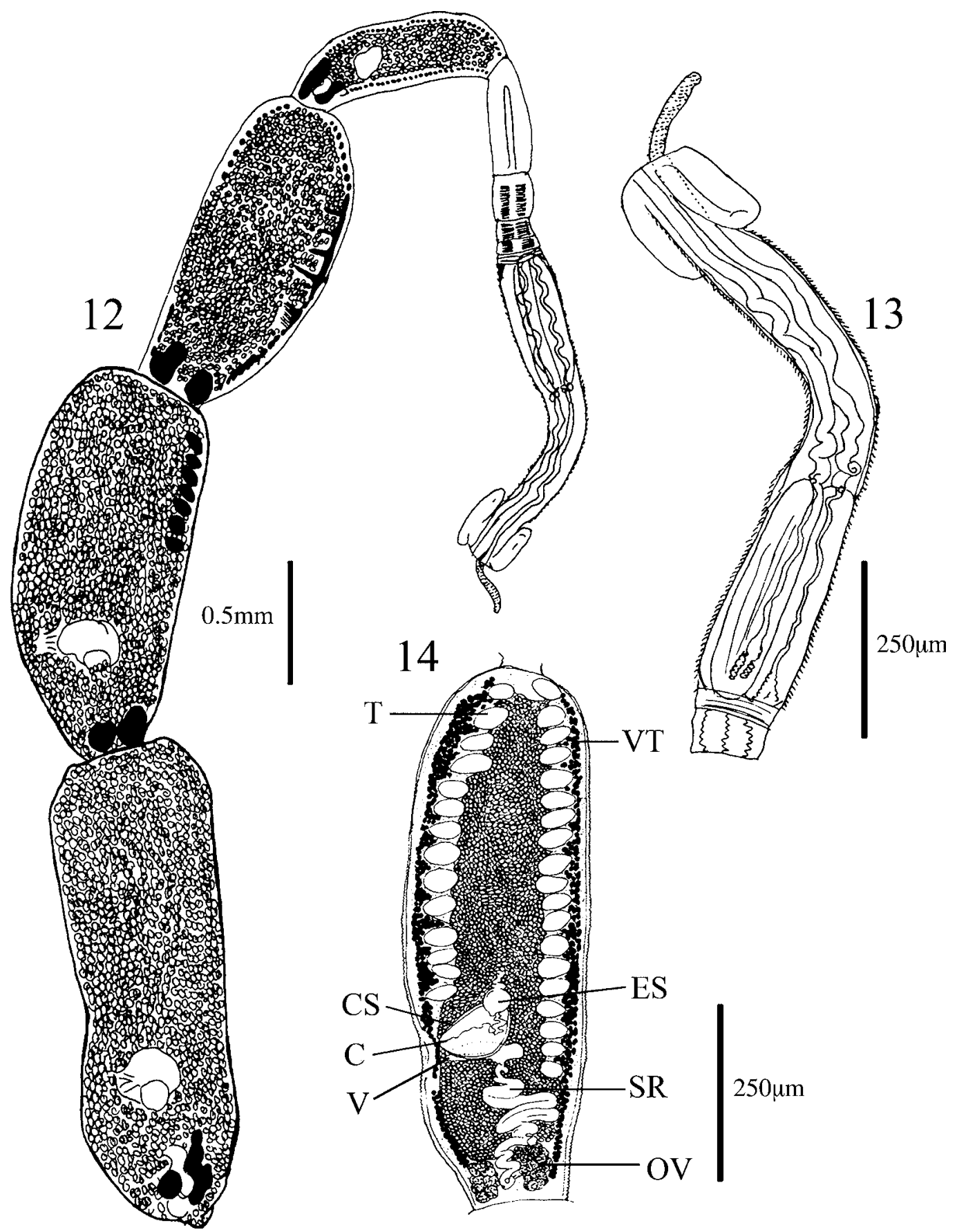

Figures 12-14. Eutetrarhynchus cortezensis n. sp. 12. Entire worm. 13. Scolex. 14. Early gravid proglottid. (C, cirrus; CS, cirrus sac; ES, external seminal vesicle; OV, ovary; SR, seminal receptacle; V, vagina; VT, vitellaria; T, testes.) 

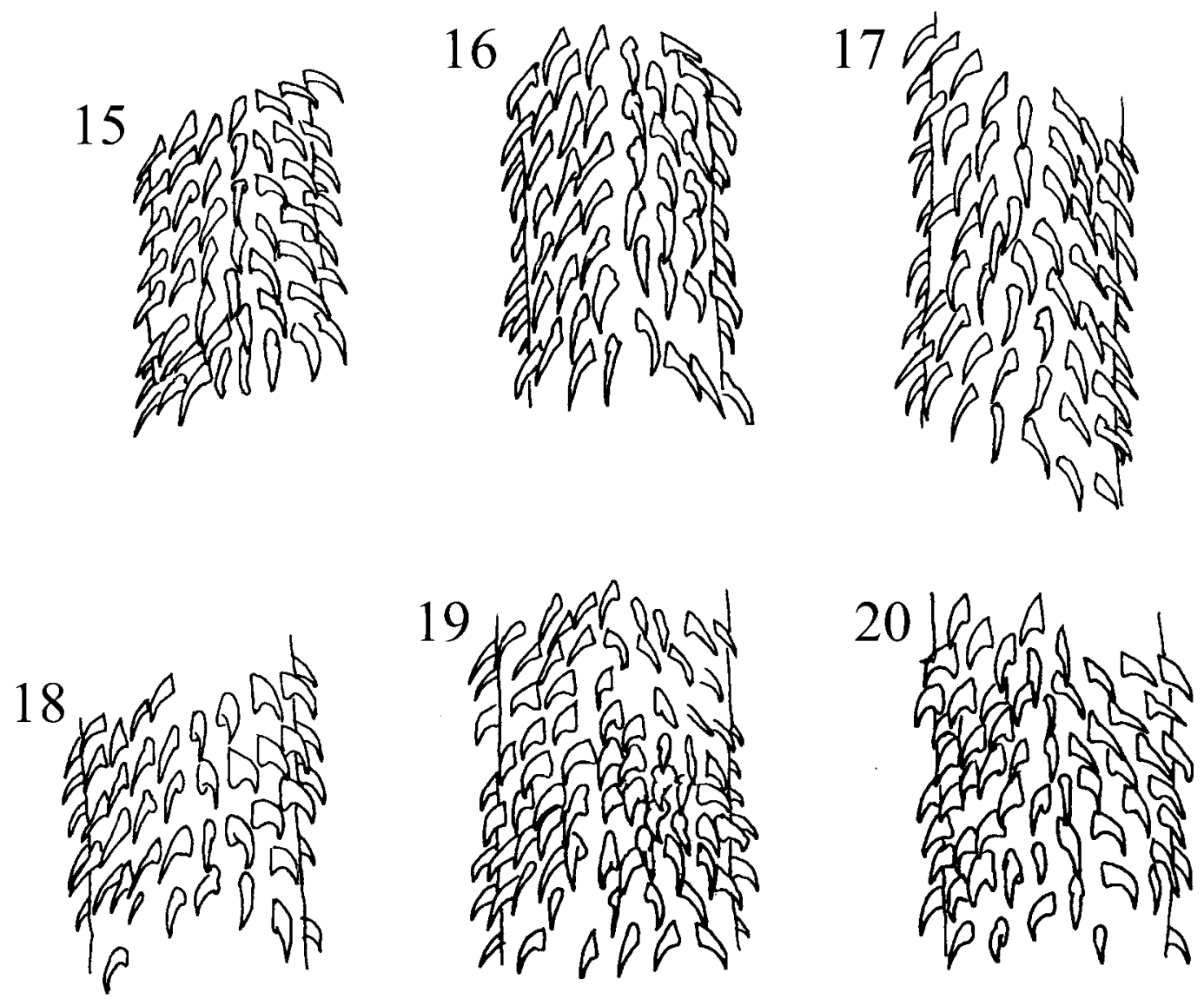

\section{$25 \mu \mathrm{m}$}

Figures 15-20. Tentacle armature of Eutetrarhynchus cortezensis n. sp. 15. Metabasal bothrial surface. 16. Metabasal external surface. 17. Metabasal antibothrial surface. 18. Basal bothrial surface. 19. Basal external surface. 20. Basal antibothrial surface.

Retractor muscles originate at base of bulbs. Prebulbar organs present.

Hooks hollow, heteromorphous, heteroacanthous typical. Slight swelling at basal region. No area of enlarged hooks. Basal armature consists of 2 half rows of 10 hooks ascending from the internal face of tentacle. Hooks $1\left(1^{\prime}\right)$ falciform 6.8 long; hooks $2\left(2^{\prime}\right)-$ $6\left(6^{\prime}\right)$ hastate 6.0 long, $7\left(7^{\prime}\right)-8\left(8^{\prime}\right)$ falciform 4.5 long, and $9\left(9^{\prime}\right)-10\left(10^{\prime}\right)$ uncinate and 3.8 long. Metabasal and distal armature is characterized by less densely packed rows of 10 falciform- and spiniform-type hooks.

Terminal gravid proglottid 992-1,700 (1,353 \pm $259.8,7)$ long by $272-828(428.5 \pm 206,7)$ wide. Indentation at genital pore; genital pore postequatorial, $30 \%$ of proglottid length from posterior end, irregularly alternating. Testes, subspheriod, in 2 rows that sometimes overlap in the anterior four fifths of mature proglottids; never seen to overreach lateral osmoregulatory canals. Testes $37-51(44.4 \pm 7.2,8)$ in number, $45-70(61 \pm 12.4,8)$ long by $15-41(23 \pm 8.5,8)$ wide. Cirrus unarmed; cirrus sac round, located in posterior third of mature and gravid proglottids, 93-134 (109.8 \pm $35.4,5)$ long by 70-180 (110.8 $\pm 43.9,5)$ wide. External seminal vesicle present. Internal seminal vesicle absent. Vagina muscular, enters genital atrium ventral to cirrus sac moving posteriorly to eventually form a large sac-like seminal receptacle at ovarian isthmus. Ovary short, $\mathrm{H}$ shaped in dorsal-ventral view, each lobe measuring 100-248 $(151.7 \pm 52.6,8)$ long by 65-140 (96 $\pm 29.6,8)$ wide in gravid proglottids. 
Uterus medial, reaching anterior margin of proglottid, tubular in mature proglottids, saccate with diverticula within gravid segments. Vitellaria circumcortical.

\section{Taxonomic summary}

Type host: Haller's round ray, Urobatis halleri (Cooper, 1863).

Type locality: Puerto Peñasco, Sonora, Mexico $\left(31^{\circ} 18^{\prime} 27^{\prime \prime} \mathrm{N} ; 113^{\circ} 32^{\prime} 52^{\prime \prime} \mathrm{W}\right)$.

Infection site: Spiral intestine, chambers 1-12.

Prevalence, mean intensity, abundance, and range of infection: $50 \%, 7.6,7.9( \pm 10.7)$, and 1-36.

Species deposited: Holotype (USNPC 92215) and paratypes (USNPC 92216, 92217) deposited in the USNPC.

Etymology: The specific epithet, "cortezensis," refers to the Sea of Cortez from which the host of the holotype was collected.

\section{Remarks}

Only 6 species of Eutetrarhynchus have been described with a scolex covered by microtriches: Eutetrarhynchus spinifer Dollfus, 1969, Eutetrarhynchus ocallaghani Beveridge, 1990, Eutetrarhynchus michiae (Southwell, 1929) Beveridge, 1990, Eutetrarhynchus micracanthus (Carvajal, Campbell and Cornford, 1976) Beveridge, 1990, Eutetrarhynchus owensi Beveridge, 1990, and E. schmidti. Among these species, E. cortezensis is unique in possessing an external seminal vesicle. Microtrichia cover the entire pars bulbosa surface of the scolex in $E$. cortezensis but do not extend beyond the region of the bulbs of the scolex in E. owensi. The basal armature of $E$. ocallaghani is distinguished by an area of increased hook numbers, whereas hook number in E. cortezensis remains consistently 10 throughout the basal armature. These taxa are also distinguished by hook shape: falciform in E. cortezensis but deltoid in E. ocallaghani. Similarly, E. cortezensis lacks the enlarged basal hooks of E. michiae, E. spinifer, and E. schmidti. Eutetrarhynchus cortezensis is further distinguished from E. schmidti by testes number (3751 vs. 56-70, respectively).

\section{Prochristianella multidum n. sp. (Figs. 21-32)}

\section{Description}

With the characteristics of the genus. Based on 12 whole mounted specimens and 2 specimens examined by SEM. Worms small, measuring 1.2-2.2 $\mathrm{mm}$ $(1.9 \pm 307.5 \mathrm{~mm}, 14)$, acraspidote, apolytic, consisting of 3-7 $(4.5 \pm 1.2,14)$ proglottids. Scolex acraspidote with 2 patelliform bothridia; pars vaginalis, pars bulbosa, and distal surfaces of bothria covered in pectinate microtriches. Proximate surface of bothria irregularly covered in filiform microtriches. Bothrial margins free, often with notably thickened rims. Pars bothridialis 85-139 (114.6 $\pm 15.2,14)$ long, pars bulbosa 164-263 $(231.9 \pm 33.8,14)$ long, bulb width 35-55 (45.2 $\pm 7.9 ; 11)$, pars vaginalis 272.8-367 (333.9 $\pm 29.4,14)$ long. Ratio pars bothridalialis:par bulbosa:pars vaginalis, 1.0:2.9:2.0. Tentacle sheaths sinuous. Retractor muscles originate at base of bulbs; prebulbar organs absent.

Hooks hollow, heteromorphous, heteroacanthous typical. Distinctive basal armature characterized by 5 rows of 9 hooks ( 3 bent-tipped falciform, 3 hastate, and 3 falciform) rising from antibothrial surface of tentacle; sixth row with 1 bent-tipped falciform hook 4.5 long, followed by 3 uncinate hooks 3.8 long, and 3 rosethorn hooks measuring 4.5 long and 4.5 width at base. Seventh row with 8 uncinate hooks of slightly varying morphology and size (3.8-4.0 long) and 1 rosethorn hook 4.5 long on the bothrial face of the tentacle. Eighth and final row slightly offset of previous row; basal armature consists of 8 uncinate hooks of slightly different morphology followed by 1 falciform hook 4.0 long. Hooks becoming less dense distally; metabasal and distal armature characterized by obliquely rising half rows of 8 falciform hooks. Longest hooks (4.5 long) on bothrial face $\left(8\left[8^{\prime}\right]\right)$. Hooks 1 (1') $^{\prime} 3.8$ long, decreasing in size from antibothrial face to external side of tentacle (hooks 2 $\left[2^{\prime}\right]$ are 3.5 , hooks $3\left[3^{\prime}\right]$ and $4\left[4^{\prime}\right]$ are 3.2, and hooks 5 [5'] are 3 long), then increasing again toward bothrial face (hooks 6 [6'] 3.4 long).

Terminal gravid proglottid $635-1,280(1,102.3 \pm$ $236.1,11)$ long by $149-327(222.1 \pm 70.7,11)$ wide. Genital pore postequatorial and alternating. Testes elliptical or subspheriod, in 2 rows that sometimes overlap in the anterior four fifths of mature proglottids. Each proglottid containing 30-37 (33.5 \pm $1.7,11)$ testes, $26-60(43.8 \pm 12.1,9)$ long by $6-20$ $(12.8 \pm 4.7,9)$ wide. Cirrus armed; cirrus sac round, located in posterior third of mature proglottids, 70$149(98.6 \pm 35,5)$ long by $50-59.5(60.4 \pm 11,5)$ wide. External and internal seminal vesicles absent. Vagina muscular, entering genital atrium posterior to cirrus sac and continuing posteriorly, eventually forming a large sac-like seminal receptacle at the isthmus of the ovary. Ovary $\mathrm{H}$ shaped in dorsoventral view, each lobe measuring 130-471 (306.3 \pm 177.9 , 


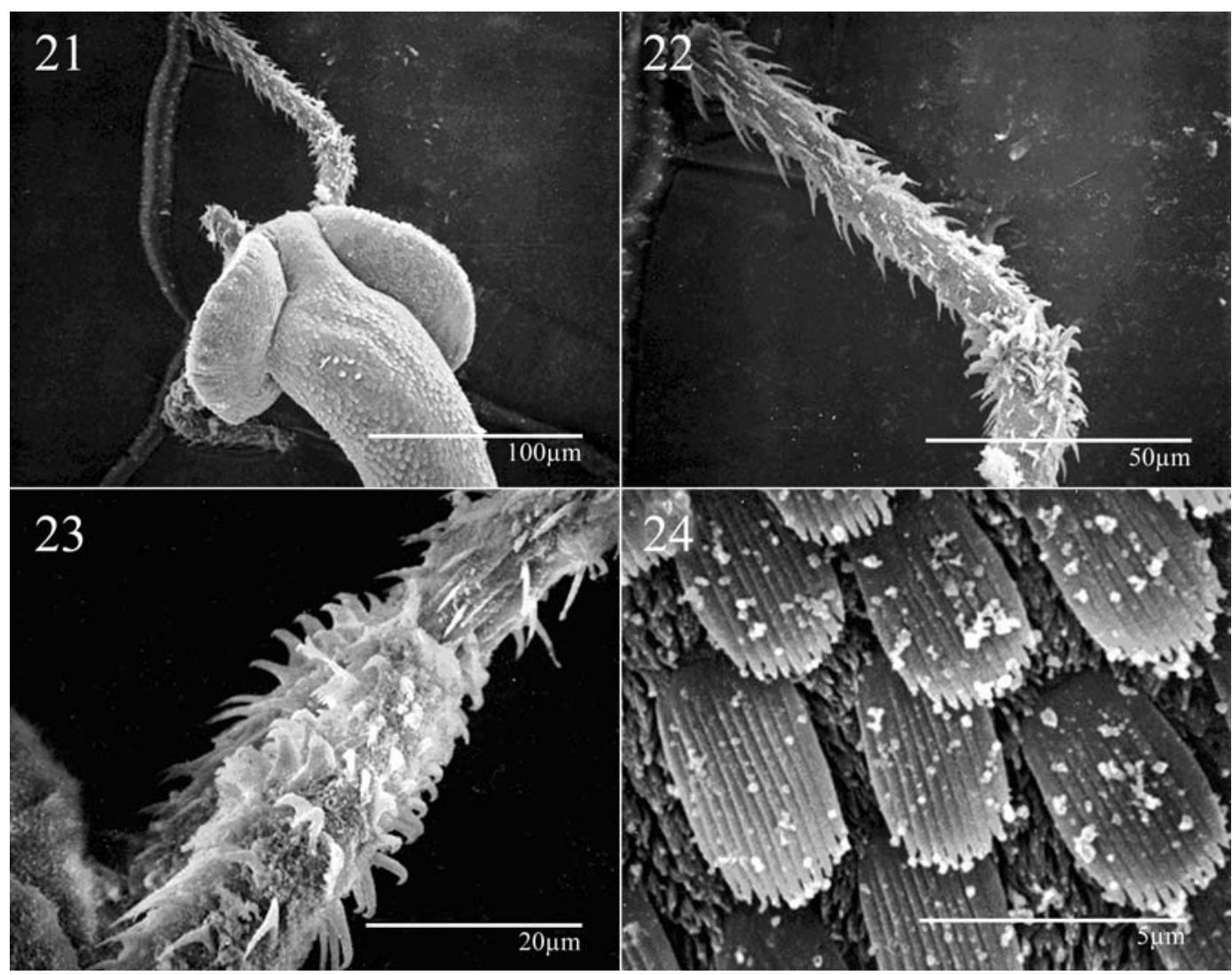

Figures 21-24. Scanning electron micrographs of Prochristianella multidum n. sp. 21. Scolex. 22. Tentacle showing basal and metabasal armature. 23. Basal portion of tentacle. 24. Pectinate microtriches from the proximal bothrial and pars bothridialis surface of the scolex.

5) long by 90-198 (131.9 \pm 49, 5) wide in gravid proglottids. Uterus is median, tubular in mature proglottids, saccate with diverticula in gravid proglottids. Vitellaria circumcortical.

\section{Taxonomic summary}

Type host: Haller's round ray, Urobatis halleri (Cooper, 1863).

Type locality: Puerto Peñasco, Sonora, Mexico (31 $\left.18^{\prime} 27^{\prime \prime} \mathrm{N} ; 113^{\circ} 32^{\prime} 52^{\prime \prime} \mathrm{W}\right)$.

Infection site: Spiral intestine, chambers 1-11.

Prevalence, mean intensity, abundance, and range of infection: 71\%, 39.7, 53.8 ( \pm 70.7$)$, and 1-289.

Species deposited: Holotype (USNPC 92218) and paratype (USNPC 92219) deposited in the USNPC.
Etymology: The specific epithet, multidum, refers to the high intensity of infection within each host individual.

\section{Remarks}

There are 11 valid species of Prochristianella: Prochristianella mooreae Beveridge, 1990, Prochristianella clarkeae Beveridge, 1990, Prochristianella butlerae Beveridge, 1990, Prochristianella papillifer (Polyarkoff, 1909) Dollfus, 1957 (=Prochristianella trygonicola Dollfus, 1946), P. minima, P. fragilis, Prochristianella hispida (Linton 1890) Campbell and Carvajal, 1975, Prochristianella tenuispinis Linton, 1890, Prochristianella thalassia (Kovacs and Schmidt, 1980) Beveridge, 1990, Prochristianella tumidula (Linton, 1890) Campbell and Carvajal, 1975, and Prochristianella spinulifera Beveridge and Jones, 2000. Prochristianella multidum is 

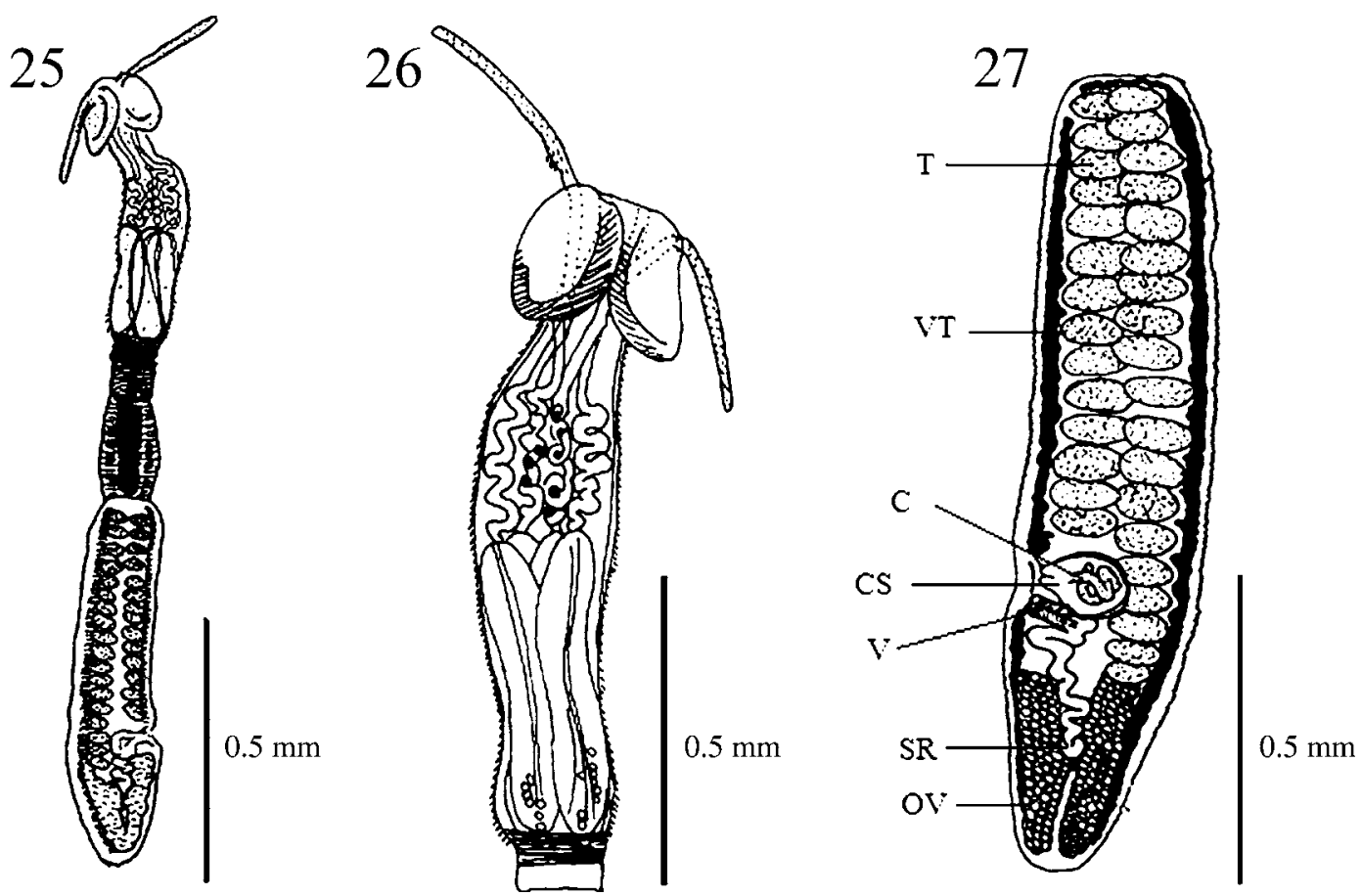

Figures 25-27. Prochristianella multidum n. sp. 25. Entire worm. 26. Scolex. 27. Mature proglottid. (C, cirrus; CS, cirrus sac; OV, ovary; SR, seminal receptacle; V, vagina; VT, vitellaria; T, testes.)

distinguished from $P$. minima, the only other species of this genus described from a urolophid host, by number of testes (30-37 vs. 18-25, respectively) and tentacle armature ( $P$. multidum possesses enlarged rosethorn hooks in sixth and seventh rows whereas P. minima does not). Prochristianella multidum has 8 rows of hooks on its basal swelling, whereas $P$. minima possesses at least 20 and $P$. butlerae, P. clarkeae, P. thalassia, P. papillifer, P. hispida, and $P$. mooreae all have 11-12 rows of hooks. Basal hook row number and hook count are similar in $P$. multidum and $P$. tumidula, but these taxa differ in both testes number (26-60 vs. 50-60, respectively) and the insertion of their metabasal hook rows (antibothrial vs. internal surface of the tentacle, respectively). The microtrichia-covered scolex of $P$. multidum further distinguishes this species from P. mooreae, P. papillifer, P. tumidula, P. fragilis, and $P$. hispida.

Only 1 other species, $P$. minima, has been reported to have hooks arising from the antibothrial tentacular surface. Beveridge and Jones (2000) noted inconsistencies in armature descriptions of species in this genus, which likely arise from the difficulty in determining the tentacle orientation in such small worms and concluded that members of Prochristianella are characterized by hook rows that originate on the bothrial surface. This description of $P$. multidum reports an arrangement that is the mirror opposite of that suggested by Beveridge and Jones (2000). Given the lack of consistency among other descriptions of Prochristianella armature, it is difficult to assess implications of this observation with regard to generic classification. More interesting is the metabasal armature of $P$. multidum, which departs from that of most other Prochristianella species by having large 1('1) hooks followed by hooks of decreasing and then increasing size. This arrangement contrasts the typical metabasal armature, where 1('1) hooks are smallest, followed by hooks of increasing length as they reach the opposite side of the tentacle.

\section{DISCUSSION}

Currently, 6 species of Rhinebothrium, R. urobatidium, Rhinebothrium bilobatum (Young, 1955) Appy and Dailey, 1977, R. biorchidum, Rhinebothrium ditesticulum Appy and Dailey, 1977, Rhinebothrium magniphallum Brooks, 1977 (Brooks and Mayes, 1980), and R. flexile (Young, 1954); 4 species of 

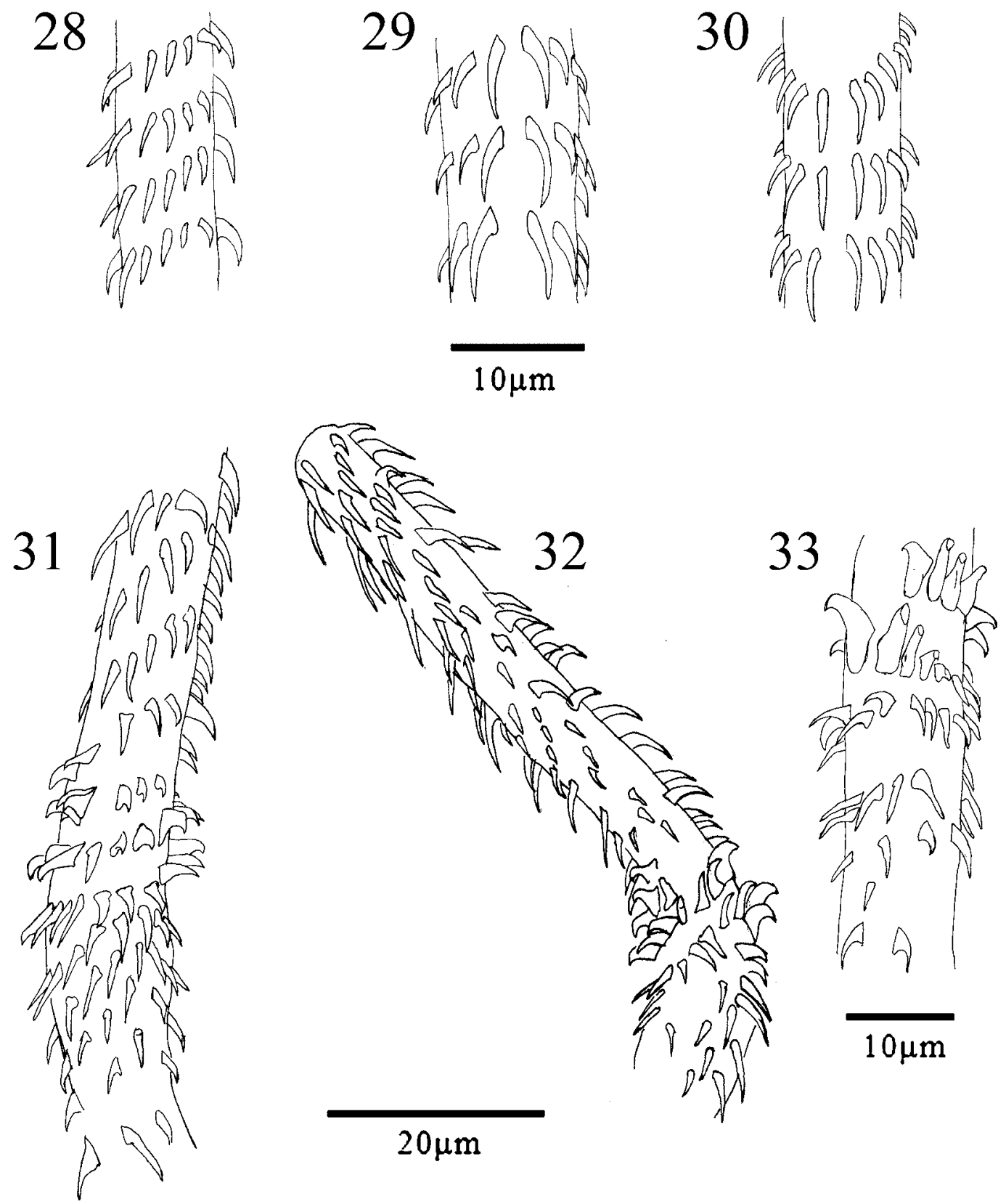

Figures 28-33. Tentacle armature of Prochristianella multidum n. sp. 28. Distal external armature. 29. Distal bothrial armature. 30. Distal antibothrial armature. 31. Basal and metabasal external armature. 32. Basal and metabasal bothrial armature, oblique view. 33. Basal antibothrial armature.

Eutetrarhynchus, E. thalassius, Eutetrarhynchus caribbensis Kovacs and Schmidt, 1980, E. schmidti, E. geraschmidti; and P. minima have been reported from urolophid hosts. In addition, several species of Acanthobothrium (Goshroy and Caira, 2001), as well as Pararhinebothroides hobergi Zamparo, Brooks, and Barriga, 1999, Phyllobothrium hallericola Church and Schmidt, 1990, Anthocephalum duszynskii Ruhnke, 1994, Grillotia trigonisbucconis (Wagener, 1854) Young, 1954, M. myliobati, O. paulinae, and 
Parachristianella trigonis (Dollfus, 1946) Young, 1954, have been described or reported from urolophid hosts.

In this article, we add 1 Prochristianella and 2 Rhinebothrium species to the known cestode fauna of $U$. halleri, bringing the total number of Prochristianella and Rhinebothrium species described from $U$. halleri to 2 and 8 , respectively. This is the first report of these genera from elasmobranches inhabiting the Gulf of California. We also present the first description of a Eutetrarhynchus species infecting $U$. halleri and the first report of a eutetrarhyncan from the Gulf of California. The descriptions presented in this study lack some specific details because the specimens were stored in formalin for $4 \mathrm{yr}$ and their condition precluded histology and examination of cross-sectional detail. Nonetheless, these descriptions are useful and we hope that other workers will supplement these descriptions with data from other specimens.

\section{ACKNOWLEDGMENTS}

We thank the students of the University of New Mexico's Marine Invertebrate Biology classes of 1994 and 1995 who helped collect and dissect $U$. halleri specimens: N. M. Abbot, K. J. Hopp, S. P. Place, E. L. Scanlon, A. L. Deans, K. M. Martinez, A. D. McLamore, L. K. Rabinoqitz, A. L. Read, and especially M. Malby who began to stain these cestodes. We also thank Drs. L. Mayberry, J. Bristol, A. Costanzo, and P. Costanzo for assisting in field collection and Jodi Gonzales for her efforts to stain and measure many of the worms collected from $U$. halleri. Paulette Ford, Rocky Mountain Research Station, provided funding for the completion of this research. This manuscript was greatly improved by the comments of 2 anonymous reviewers. Finally, these descriptions would not have been possible without the instruction and advice on SEM analysis of Dr. S. Stricker, UNM Biology.

\section{LITERATURE CITED}

Appy, R., and M. D. Dailey. 1977. A new species of Rhinebothrium (Cestoda: Tetraphyllidea) and redescription of three Rhinebothriate species from the round stingray, Urolophus halleri Cooper in Southern California. Bulletin of the Southern California Academy of Sciences 76:116-127.

Beveridge, I. 1990. Taxonomic revision of Australian Eutetrarhynchidae Guiart (Cestoda: Trypanorhyncha). Invertebrate Taxonomy 4:785-845.

Beveridge, I., and M. K. Jones. 2000. Prochristianella spinulifera $\mathrm{n}$. sp. (Cestoda: Trypanorhyncha) from
Australian dasyatid and rhinobatid rays. Systematic Parasitology 47:1-8.

Brooks, D. R., and T. L. Deardorff. 1988. Rhinebothrium devaneyi n. sp. (Eucestoda: Tetraphyllidea) and Echinocephalus overstreeti Deardorff and Ko, 1983 (Nematoda: Gnathostomatidae) in a thorny back ray, Urogymnus asperrimus, from Enewetak Atoll, with phylogenetic analysis of both species groups. Journal of Parasitology 74:459-465.

Brooks, D. R., and M. A. Mayes. 1980. Cestodes in four species of euryhaline stingrays from Columbia. Proceedings of the Helminthological Society of Washington 47:22-29.

Campbell, R. A. 1970. Notes on Tetraphyllidean cestodes from the Atlantic coast of North America, with descriptions of two new species. Journal of Parasitology 56:498-508.

Campbell, R. A. 1975. Tetraphyllidea cestodes from western North Atlantic Selachians with descriptions of two new species. Journal of Parasitology 61: 265-270.

Campbell, R. A., and J. Carvajal. 1975. A revision of some Trypanorhynchs from the western North Atlantic described by Edwin Linton. Journal of Parasitology 61 1016-1022.

Carvajal, J., R. A. Campbell, and E. M. Cornford. 1976. Some trypanorhynch cestodes from Hawaiian fishes, with descriptions of four new species. Journal of Parasitology 62:70-77.

Compagno, L. J. V. 1988. Sharks of the Order Carcharhiniformes. Princeton University Press, Princeton, New Jersey. 486 pp.

Cornford, E. M. 1974. Two tetraphyllidean cestodes from Hawaiian stingrays. Journal of Parasitology 60: 942-948.

Dailey, D. D., and J. Carvajal. 1976. Helminth parasites of Rhinobatos planiceps Garman 1880 including two new species of cestodes, with comments on host specificity of the genus Rhinebothrium Linton 1890. Journal of Parasitology 62:939-942.

Dollfus, R. P. 1946. Notes diverses sure des tétrarhynques. Mémoires du Muséum National d'Histoire Naturelle, Paris, nouvelle série 22:179-220.

Dollfus, R. P. 1969. De Quelques cestodes tétrarhynques (hétéracanthes et pécilacanthes) récoltés ches des poissons de la méditteranée. Vie et Milieu 20:491-514.

Dollfus, R. P. 1974. D'un Eutetrarhynchus (Cestode Tétrarhynque) au stade pre-adulte chez us Urolophus (Selachii, Dasyatidae): Eutetrarhynchus geraschmidti. Bulletin du Muséum National d'Histoire Naturelle, Paris, série 3 207:147-151.

Eschmeyer, W. N., C. J. Ferraris, Jr., M. D. Hoang, and D. J. Long. 1998. Catalog of Fishes: Vols. II and III. California Academy of Sciences, San Francisco, California. 2905 pp.

Euzet, L. 1954. Parasites de poissons de mer Quest Africains recoltés par J. Cadenat. 1. Cestode Tetraphyllides de Selaciens. Zoological Bulletin de l'Institut Français d'Afrique Noire. Série A. Sciences naturelles. 16:126-138.

Euzet, L. 1956. Thèses présentées à la Faculte des Sciences de Montellier pour Obtenir le grade de Docteur dès Sciences Naturelles. 1. Rescherches sure les Cestodes Tétraphyllides des sélaciens des côtes de France. 
Causse, Grailee and Castelneau, Montpellier, France. $263 \mathrm{pp}$.

Euzet, L., and J. Carvajal. 1973. Rhinebothrium (Cestoda: Tetraphyllidea) parasites de Raies du genre Psammobatis au Chili. Bulletin du Muséum National d'Histoire Naturelle, Paris, série 3. 101:779-787.

Friggens, M. M., and J. H. Brown. 2005. Niche selection in the cestode communities of two stingrays. Oikos 108:76-84.

Ghoshroy, S., and J. N. Caira. 2001. Four new species of Acanthobothrium (Cestoda: Tetraphyllidea) from the whiptail stingray Dasyatis brevis in the Gulf of California, Mexico. Journal of Parasitology 87:354-372.

Heinz, M. L., and M. D. Dailey. 1974. The Trypanorhyncha (Cestoda) of elasmobranch fishes from Southern California and Northern Mexico. Proceedings of the Helminthological Society of Washington 41: $161-169$.

Huber, P. M., and G. D. Schmidt. 1985. Rhinebothrium biorchidum n. sp., a tetraphyllidean cestode from a yellow-spotted stingray, Urolophus jamaicensis, in Jamaica. Journal of Parasitology 71:1-3.

Joyeux, C., and J. G. Baer. 1936. Faune de France. 30. Cestodes. Lechevalier, Paris. 613 pp.

Khalil, L. F., A. Jones, and L. A. Bray. 1990. Keys to the Cestode Parasites of Vertebrates. University Press, Cambridge, Massachusetts. $751 \mathrm{pp}$.

Kovacs, K. J., and G. D. Schmidt. 1980. Two new species of cestode (Trypanorhyncha, Eutetrarhynchidae) from the yellow-spotted Stingray, Urolophus jamaicensis. Proceedings of the Helminthological Society of Washington 47:10-14.
Linton, E. 1890. Notes on entozoa of marine fishes of New England II. Annual Report of the U.S. Commission on Fish and Fisheries for 1887. Washington D.C., U.S.A. 17:719-899.

McVicar, A. H. 1979. The distribution of cestodes within the spiral intestine of Raja naevus Muller \& Henle. Journal of Parasitology 9:165-176.

Pritchard, M. H., and O. W. Kruse. 1982. The Collection and Preservation of Animal Parasites. University of Nebraska Press, Lincoln, Nebraska. 281 pp.

Rego, A. A., and A. P. L. Dias. 1976. Estudo de cestoides de peixes de Brasil a nota: Cestoides de raias fluviais Paratrygonidae. Revista Brasileira de Biologia 36: 941-956.

Williams, H. H. 1958. Some Tretraphyllidea (Cestoda) from the liverpool school of tropical medicine. Revue Suisse de Zoologie 65:867-868.

Williams, H. H. 1964. Some new and little known cestodes from Australian elasmobranchs, with a brief discussion on their possible use in problems in host taxonomy. Parasitology 54:737-748.

Yanhai, W., and Y. Wenchuan. 2001. Rhinebothrium xiamenensis n. sp. (Eucestoda: Tetraphyllidea) in Dasyatis zugei from the coast of Xiamen, China. Journal of Parasitology 87:185-187.

Young, R. T. 1954. Cestodes of sharks and rays in southern California. Proceedings of the Helminthological Society of Washington 21:106-112.

Young, R. T. 1955. Two new species of Echineibothrium form the stingray Urobatis halleri. Transactions of the American Microscopy Society 74: 232-234. 